\title{
Pemodelan Dry Dam dengan HEC-HMS di Daerah Aliran Sungai Bringin
}

\author{
Fitria Maya Lestari ${ }^{(1)}$, Suseno Darsono ${ }^{(2)}$, Dyah Ari Wulandari ${ }^{(3)}$ \\ 1,2,3Program Studi Teknik Sipil, Universitas Diponegoro
}

Email: ${ }^{1}$ maya.prasasti@yahoo.co.id, ${ }^{2}$ sdarsono@ $@$ hotmail.com,

3dyahariwulandari@yahoo.co.id

\begin{tabular}{l}
\hline Tersedia Online di \\
\hline http://www.jurnal.unublitar.ac.id/ \\
index.php/briliant \\
\hline Sejarah Artikel \\
\hline Diterima pada 29 Juni 2020 \\
Disetujui pada 20 Agustus 2020 \\
Dipublikasikan pada 31 Agustus \\
2020 Hal. 602-611 \\
\hline
\end{tabular}

Kata Kunci:

Banjir; HEC-HMS; dry dam

\section{DOI:}

http://dx.doi.org/10.28926/briliant .v3i4.491

\begin{abstract}
Abstrak: Banjir yang terjadi di Sungai Bringin menyebabkan kerugian finansial bagi masyarakat di sekitarnya. Penelitian ini bermaksud menentukan system pengendali banjir yang paling efisien dan merespon keinginan masyarakat sekitar Sungai Bringin tentang upaya-upaya pengelolaan banjir. Perhitungan debit banjir dilakukan dengan menggunakan pemodelan (Hydrologic Modeling System) HEC-HMS. Hasil analisis diperoleh bahwa debit untuk kondisi eksisting di hilir Sungai Bringin dengan kala ulang 100th sebesar 425,7 m3/dt. Pada perencanaan, terdapat delapan lokasi embung potensi. Pada analisis di rencanakan 2 simulasi yaitu pengendalian banjir dengan embung dan dry dam. Hasil analisis debit dengan adanya rencana embung, ditinjau pada hilir Sungai Bringin dapat mereduksi banjir sebesar 151,8 m3/dt dengan Persentase 34,5 persen. Sedangkan hasil simulasi menggunakan dry dam dapat mereduksi banjir sebesar 210,8 m3/dt, dengan Persentase sebesar 48,3 persen. Dari hasil analisis diketahui bahwa pembangunan beberapa dry dam merupakan teknik terpilih sebagai upaya peredaman debit. Metode dry dam merupakan metode yang ideal untuk mengatasi banjir di Sungai Bringin.
\end{abstract}

\section{PENDAHULUAN}

Banjir merupakan permasalahan umum yang terjadi di sebagian wilayah di Indonesia, terutama di wilayah padat penduduk misalnya di daerah perkotaan. Kerugian yang dapat ditimbulkannya cukup besar, baik dari segi materi maupun kerugian jiwa, maka sudah selayaknya permasalahan banjir perlu mendapatkan perhatian yang serius (Kodoatie dan Sugiyanto, 2002).

Semarang Barat berhubungan langsung dengan jalur pantura sering mengalami banjir. Kejadian banjir yang menggenangi wilayah Mangkang Wetan di karenakan luapan Sungai Plumbon dan Sungai Bringin. Akibatnya luapan terjadi di sisi kanan dan sisi kiri sungai maupun saluran irigasi dan menggenangi selama satu jam, luapan terjadi karena parapet yang baru dibangun oleh Dinas Pekerjaan Umum (PU) Kota Semarang jebol Karena debit air yang terlampau besar selain itu ada penyumbatan balok kayu dan sampah pada bekas jalan darurat Proyek Jalan Tol di bawah bendung.

Berdasarkan data Bappeda, pada akhir tahun 2010 banjir menyebabkan kemacetan di daerah pantura sehingga menimbulkan lumpuhnya perekonomian. Banjir tersebut juga menggenangi daerah lokasi menggenangi daerah lokasi studi, 
yang melumpuhkan aktivitas warga. Melihat kasus di atas diperlukan upaya pencegahan terjadinya banjir dengan pengaturan debit saat hujan datang.

Beberapa studi mengenai Pengendalian Banjir di DAS Bringin yang telah dilakukan, di antaranya adalah sebagai berikut Penanganan Sungai Bringin dilakukan beberapa penanganan yaitu meliputi perhitungan daerah resapan, inflow, dan outflow pada Sungai Bringin yang mencetuskan ide untuk melakukan upaya pembangunan long storage pada Sungai Bringin ( Wibowo et al.2014). Detail Desain Pengelolaan Dan Pengendalian Banjir Sistem Sungai Semarang Barat tahun 2015. Pekerjaan ini dilakukan oleh PT. Adiguna Mitra Terpercaya Consultan dengan pemilik pekerjaan adalah BBWS Pemali Juana, diketahui debit eksisting Q100th 435,4 m3/dt masih mengalami limpasan pada hilir Sungai Bringin maka tidak dapat dilakukan perbesaran penampang sungai. Kajian perlintasan jalan tol dan Sungai Bringin yang ramah lingkungan, tidak menambah dampak buruk didaerah hilir dan berpengaruh positip pada morfologi sungai (Darsono et al, 2016).

Beberapa negara maju telah melakukan inovasi dalam pengendalian banjir dengan menggunakan dry dam contohnya seperti Bendungan Masudagawai di Jepang, Bendungan Miami's Conservancy District Ohio di Amerika Serikat (Oshikawa, 2019). Dry dam merupakan bendungan yang berlokasi di palung sungai dengan maksud agar tidak ada pembebasan lahan pemukiman milik penduduk sehingga sesuai untuk diterapkan pada daerah perkotaan dengan pemukiman padat penduduk. Dry dam ini hanya berfungsi pada saat kondisi hujan saja untuk menahan sebagian debit, sedangkan pada waktu tidak ada hujan maka kondisinya kering dan hanya seperti aliran sungai. Beberapa kekurangannya adalah volume tampungan kecil karena sulit menemukan lokasi bangunan untuk perencanaan dry dam yang besar (ICOLD,2018).

Dry Dam merupakan salah satu alternatife untuk pengendalian banjir di daerah perkotaan, karena dengan lahan terbatas dapat menahan banjir secara maksimal. Metode ini sesuai untuk diterapkan di DAS Bringin yang kondisinya saat ini padat penduduk Oleh karena itu penelitian tentang Penanggulangan Banjir dengan Dry Dam di DAS Bringin perlu dilakukan.

Lemperiere (2006) telah menyatakan bahwa "fungsi dari bendungan yang akan datang hanya digunakan untuk mengurangi aliran air yang benar - benar kering. Desain dry dam sangat berbeda dari bendungan multipurpose dan biaya mereka jauh lebih rendah untuk penyimpanan yang sama. Masih ada beberapa faktor yang belum diketahui seperti laju sedimentasi, pola dan aliran di hulu bendungan, jumlah saluran bawah, dan dimensi cekungan yang masih berdiri (tinggi, panjang, lebar), bergantung pada hidrograf banjir dan tingkat air. Jumlah saluran bawah, dan dimensi cekungan yang masih berdiri (tinggi, panjang, lebar), tergantung pada hidrograf banjir dan tingkat air.

Kajian yang selama ini dilakukan, belum ada pembahasan mengenai reduksi debit banjir dengan menggunakan dry dam. Oleh karena itu penelitian ini dilakukan untuk mengetahui efektifitas dry dam pada pengendalian banjir di Sungai Bringin. 


\section{METODE}

\section{Pengumpulan Data}

Pengumpulan data dilakukan dengan metode observasi data. Adapun data yang diperlukan untuk analisis ini adalah sebagai berikut:

a. Data curah hujan. Data curah hujan berupa data hujan harian dengan lama atau panjang data curah hujan untuk masing-masing stasiun hujan minimal 10 tahun. Data curah hujan diambil dari 3 (tiga) stasiun hujan yang berada di sekitar DAS antara lain Stasiun Hujan Mangkang Waduk, Stasiun Hujan Simongan dan Stasiun Hujan Sigotek. Data curah hujan diperoleh dari beberapa sumber antara lain Badan Meteorologi, Klimatologi, dan Geofisika (BMKG) Semarang, Balai Besar Wilayah Sungai (BBWS) Pemali-Juana, dan PU Kota Semarang

b. Peta tata guna lahan. Peta tata guna lahan yang digunakan berupa shapefile dan diperoleh dari beberapa sumber seperti BBWS Pemali Juana dan Bappeda Kota Semarang.

c. Peta jenis tanah. Peta jenis tanah yang digunakan dalam analisis debit banjir merupakan peta keluaran dari Pusat Penelitian Tanah, Bogor.

d. Peta topografi. Data topografi/ Digital Elevation Model (DEM) yang diperlukan dalam penelitian ini berupa data raster. Data ini akan digunakan dalam analisis potensi lokasi Embung dalam. Data topografi/ Digital Elevation Model (DEM) diperoleh dari Badan Informasi Geospasial (BIG).

\section{Analisis Data}

a. Pengolahan Data Hidrologi

- Perhitungan curah hujan rata-rata tahunan

- Penentuan luas pengaruh stasiun hujan dengan metode Polygon Thiesen.

- Perhitungan curah hujan rencana

b. Perhitungan debit banjir

Analisis debit banjir menggunakan software HEC HMS. Analisis debit banjir rencana pada penelitian ini dilakukan dengan menggunakan metode Hidrograf Satuan Sintetis tak berdimensi Soil Conservation Service (SCS) dengan menggunakan perangkat lunak HEC-HMS.

Konsep dasar perhitungan dari model HEC-HMS adalah data hujan sebagai input air untuk satu atau beberapa sub daerah tangkapan air (sub basin) yang sedang dianalisis. Jenis datanya berupa intensitas, volume, atau komulatif volume hujan. Setiap sub basin dianggap sebagai suatu tandon yang non linier dimana inflownya adalah data hujan. Aliran permukaan, infiltrasi, dan penguapan adalah komponen yang keluar dari sub basin.

Pada basin model tersusun atas gambaran fisik daerah tangkapan air dan sungai. Elemen-elemen hidrologi berhubungan dengan jaringan yang mensimulasikan proses limpasan permukaan (run off). Pemodelan hidrograf satuan memiliki kelemahan pada luas area yang besar, maka perlu dilakukan pemisahan area basin menjadi beberapa sub basin berdasarkan percabangan sungai, dan perlu diperhatikan batas-batas luas daerah yang berpengaruh pada daerah tangkapan air tersebut. 


\section{c. Pemodelan Dry Dam}

Pemodelan embung menggunakan Software HEC-HMS yaitu dengan memasukan model reservoir pada Software HEC-HMS. Pemodelan Small Dam maupun dry dam akan di input luas tampungan beserta volume tampungan embung. Sesuai dengn kurva tampungan embung rencana. Pada dry dam akan dipasang beberapa saluran pengelak berupa outlet pada elevasi dasar embung yang dibuat permanen. Setelah di running pada HEC-HMS, akan di dapat hydrograph banjir pada tiap Embung dan ditinjau pada titik hilir Sungai Bringin. Selanjutnya akan di analisis berapa besar debit banjir yang dapat direduksi dengan adanya Small Dam maupun Dry Dam.

\section{HASIL}

\section{Polygon Thiessen}

Metode perhitungan berdasarkan rata-rata timbang (weighted average), merupakan cara perhitungan yang memberikan proporsi luasan daerah pengaruh stasiun hujan untuk mengakomodasi ketidak seragaman jarak. Daerah pengaruh dibuat dengan menggambarkan garis-garis sumbu tegak lurus terhadap garis penghubung antara dua stasiun hujan terdekat.

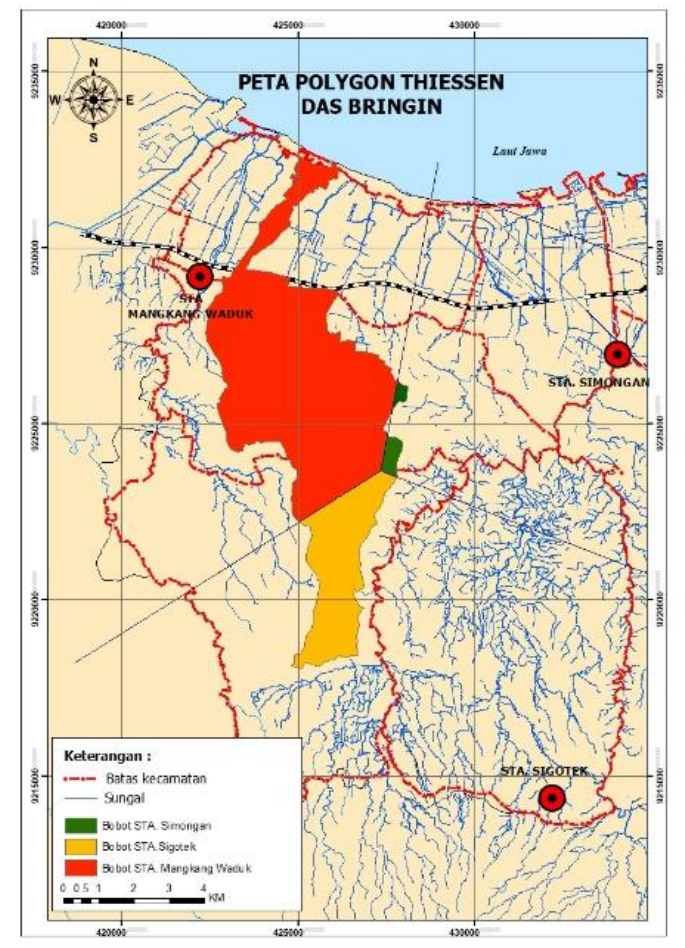

Gambar 1. Peta Polygon Thiessen DAS Bringin

Berdasarkan hasil analisis Polygon Thiessen pada Gambar 1, didapat bahwa terdapat tiga stasiun hujan yang memberikan pengaruh pada DAS Bringin. Stasiun Hujan yang lebih dominan adalah Stasiun Hujan Mangkang Waduk sebesar 76\%, Stasiun Sigotek sebesar 22\% dan Satasiun Hujan Simongan sebesar $2 \%$. 


\section{PEMBAHASAN}

\section{Penentuan Curah Hujan Maksimum}

Besarnya curah hujan maksimum harian rata-rata DAS yang dihitung dengan Metode Poligon Thiessen, mempertimbangkan daerah pengaruh tiap titik pengamatan.Analisis ini dimaksudkan untuk mengetahui curah hujan harian maksimum rata-rata yang terjadi pada daerah tangkapan (catchment area) tersebut yaitu dengan mengalikan data curah hujan harian maksimum yang didapat dari stasiun penakar hujan, dengan bobot pengaruh tiap stasiun pengukur hujan. Dari curah hujan harian maksimum rata - rata stasiun dibandingkan, yang mempunyai nilai curah hujan harian maksimum rata-rata paling tinggi diambil sebagai curah hujan areal DAS Bringin.

Data curah hujan harian maksimum kemudian diuji dengan menggunakan empat distribusi, yaitu, gumbel, log normal, log pearson III dan distribusi normal. Berdasarkan hasil perhitungan parameter statistik curah hujan rencana dengan berbagai metode distribusi, selanjutnya dipilih distribusi yang paling mendekati atau cocok dengan data yang ada. Dari hasil analisis diperoleh bahwa parameter statistik yang memenuhi syarat adalah Distribusi Normal dengan besaran kala ulang hujan seperti pada Tabel 1.

Tabel 1. Kala Ulang Hujan DAS Bringin

\begin{tabular}{|l|c|c|}
\hline No & $\begin{array}{c}\text { Kala Ulang } \\
\text { Tahun }\end{array}$ & $\begin{array}{c}\text { Hujan } \\
\text { (mm) }\end{array}$ \\
\hline 1 & 2 & 110 \\
\hline 2 & 5 & 151 \\
\hline 3 & 10 & 172 \\
\hline 4 & 20 & 190 \\
\hline 5 & 50 & 210 \\
\hline 6 & 100 & 223 \\
\hline 7 & 200 & 235 \\
\hline 8 & 500 & 250 \\
\hline 9 & 1000 & 260 \\
\hline
\end{tabular}

\section{Pemodelan Debit Banjir dengan HEC-HMS}

Model HEC-HMS mengemas berbagai macam metode yang digunakan dalam analisa hidrologi. Dalam pengoprasiannya menggunakan basis sistem windows, sehingga model ini menjadi dapat dipelajari, tetapi tetap dilakukan dengan pendalaman dan pemahaman dengan model yang digunakan. Hasil output yang berupa debit tersebut akan digunakan untuk debit rencana dalam perhitungan selanjutnya, yaitu dalam pengendalian banjir DAS Bringin.

Di dalam model ini, terdapat beberapa macam metode hidrograph sintetik. Sedangkan untuk menyelesaikan analisis hidrologi ini, digunakan satuan sintetik dari SCS dengan menganalisa beberapa parameter maka hidrograf ini dapat disesuaikan dengan kondisi daerah khususnya DAS Bringin. Gambar 2 merupakan gambaran model DAS Bringin. Sedangkan Gambar 3 merupakan hydrograph banjir Sungai Bringin kondisi existing hasil output dari model HECHMS. 


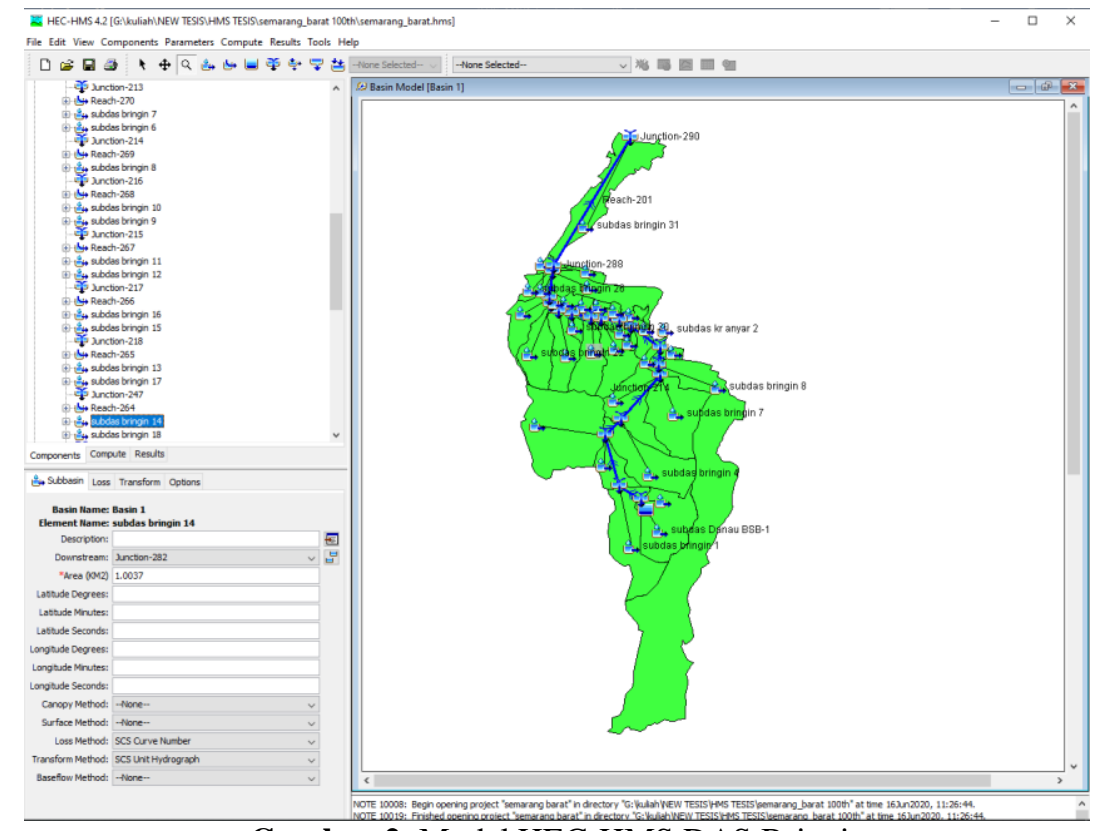

Gambar 2. Model HEC-HMS DAS Bringin

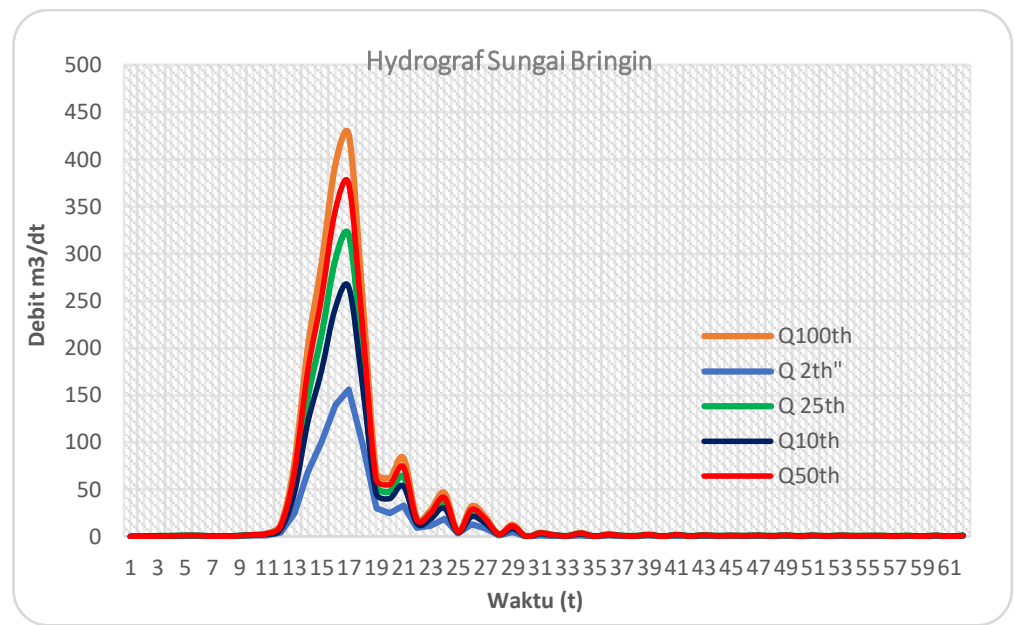

Gambar 3. Hidrograf Debit Banjir kondisi eksisting di Hulu Sungai Bringin

\section{Pemodelan Banjir Rencana dengan Embung}

Pada penelitian ini, dilakukan 2 simulasi untuk reduksi banjir yaitu dengan embung dan dry dam. Dari peta topografi di buat beberapa lokasi potensi embung berdasarkan kontur yang berupa cekungan. Penentuan lokasi Embung harus memperhatikan beberapa faktor yaitu cekungan yang cukup untuk menampung air, terutama pada lokasi yang keadaan geotekniknya tidak lolos air, sehingga kehilangan airnya hanya sedikit. Selain itu lokasinya terletak di daerah manfaat yang memerlukan air sehingga jaringan distribusinya tidak begitu panjang dan tidak banyak kehilangan energi, serta / terletak di dekat jalan, sehingga jalan masuk (access road) tidak begitu panjang dan lebih mudah ditempuh. (Soedibyo, 1993). Terdapat 8 lokasi potensi Embung yang dapat digunakan sebagai penelitian. Lokasi-lokasi embung tersebut dapat dilihat pada Gambar 4 dan Tabel 2. 


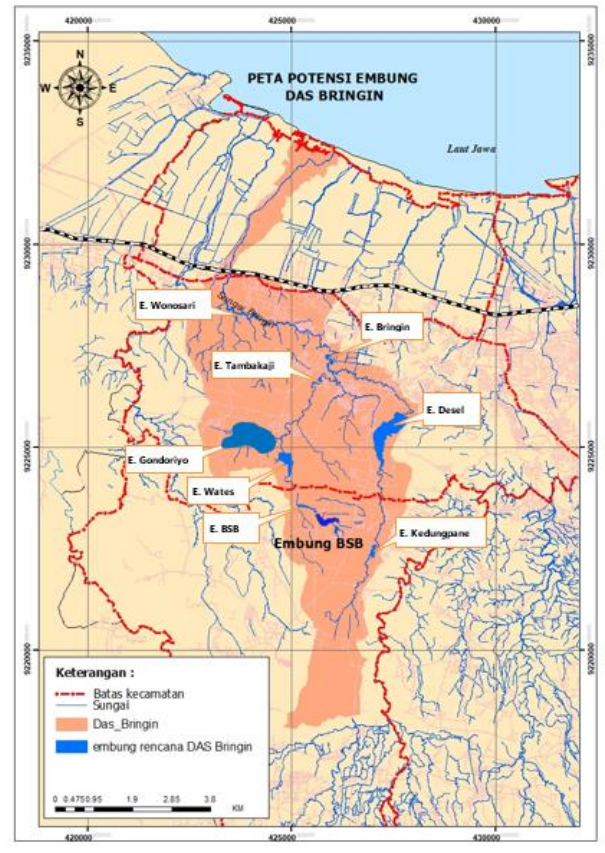

Gambar 4. Lokasi Potensi Embung di DAS Bringin

Tabel 2. Potensi Embung di DAS Bringin

\begin{tabular}{|c|l|l|l|c|c|c|}
\hline \multirow{2}{*}{ No } & \multirow{2}{*}{ Nama Embung } & \multirow{2}{*}{ Kelurahan } & \multirow{2}{*}{ Kecamatan } & \multicolumn{2}{|c|}{ Koordinat } & CA \\
\cline { 5 - 7 } & & & $\mathrm{x}$ & $\mathrm{y}$ & $\mathrm{km} 2$ \\
\hline 1 & Embung BSB & Pesantren & Mijen & $7^{\circ} 1^{\prime} 26.56 " \mathrm{~S}$ & $110^{\circ} 19^{\prime} 24.84 " \mathrm{E}$ & 1.67 \\
\hline 2 & Embung Wates & Wates & Ngaliyan & $7^{\circ} 0^{\prime} 47.11^{\prime \prime} \mathrm{S}$ & $110^{\circ} 19^{\prime} 9.83^{\prime \prime} \mathrm{E}$ & 1.73 \\
\hline 3 & Embung Gondoriyo & Wates & Ngaliyan & $7^{\circ} 0^{\prime} 26.15^{\prime \prime} \mathrm{S}$ & $110^{\circ} 18^{\prime} 48.26 " \mathrm{E}$ & 3.47 \\
\hline 4 & Embung Bringin & Bringin & Ngaliyan & $6^{\circ} 59^{\prime} 44.88^{\prime \prime} \mathrm{S}$ & $110^{\circ} 19^{\prime} 37.66 " \mathrm{E}$ & 3.07 \\
\hline 5 & Embung Tambakaji & Tambakaji & Ngaliyan & $6^{\circ} 59^{\prime} 24.75^{\prime \prime} \mathrm{S}$ & $110^{\circ} 19^{\prime} 45.02 " \mathrm{E}$ & 3.52 \\
\hline 6 & Embung Kedungpane & Kedungpane & Mijen & $7^{\circ} 1^{\prime} 58.78 " \mathrm{~S}$ & $110^{\circ} 20^{\prime} 23.60^{\prime \prime} \mathrm{E}$ & 5.33 \\
\hline 7 & Embung Ngaliyan & Ngaliyan & Ngaliyan & $7^{\circ} 0^{\prime} 19.38^{\prime \prime} \mathrm{S}$ & $110^{\circ} 20^{\prime} 40.32 " \mathrm{E}$ & 2.51 \\
\hline 8 & Embung Wonosari & Tambakaji & Ngaliyan & $6^{\circ} 58^{\prime} 49.39 " \mathrm{~S}$ & $110^{\circ} 18^{\prime} 36.06^{\prime \prime} \mathrm{E}$ & 2.99 \\
\hline
\end{tabular}

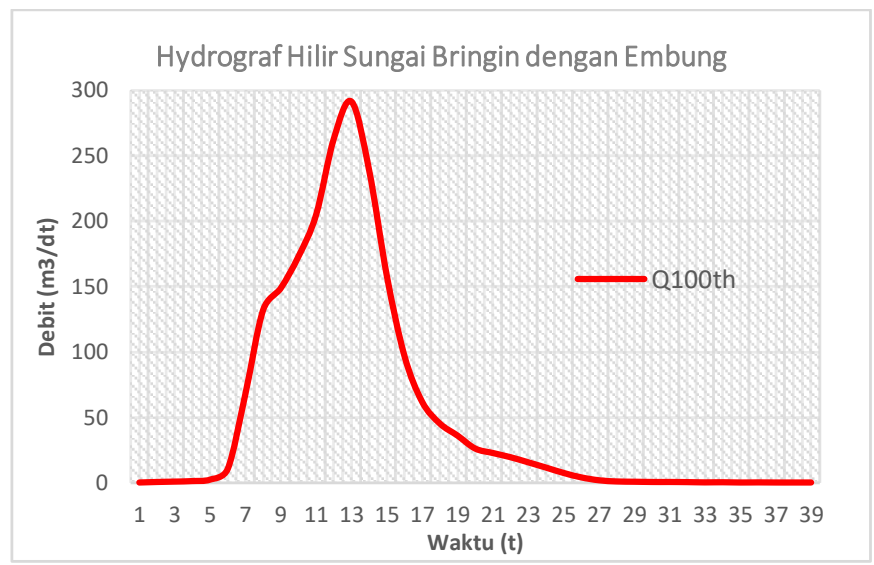

Gambar 5. Hydrograf Banjir dengan Rencana Embung pada Sungai Bringin 
Selanjutnya model HEC-HMS dianalisis dengan penambahan embung yang berfungsi sebagai pengendali banjir. Adapun hasilnya diketahui bahwa debit banjir Sungai Bringin berkurang seperti ditampilkan pada Gambar 5.

\section{Pemodelan Banjir Rencana dengan Dry Dam}

Analisis selanjutnya adalah pemodalan dry dam pada model HEC-HMS. Perbedaan pemodelan terdapat pada penambahan outlet dengan input data yang telah ada. Data outlet diinputkan pada semua Embung potensi yang ada di DAS Bringin. Adapun hasilnya diperoleh hydrograph banjir yang lebih rendah dibandingkan dengan embung seperti ditampilkan pada Gambar 6.

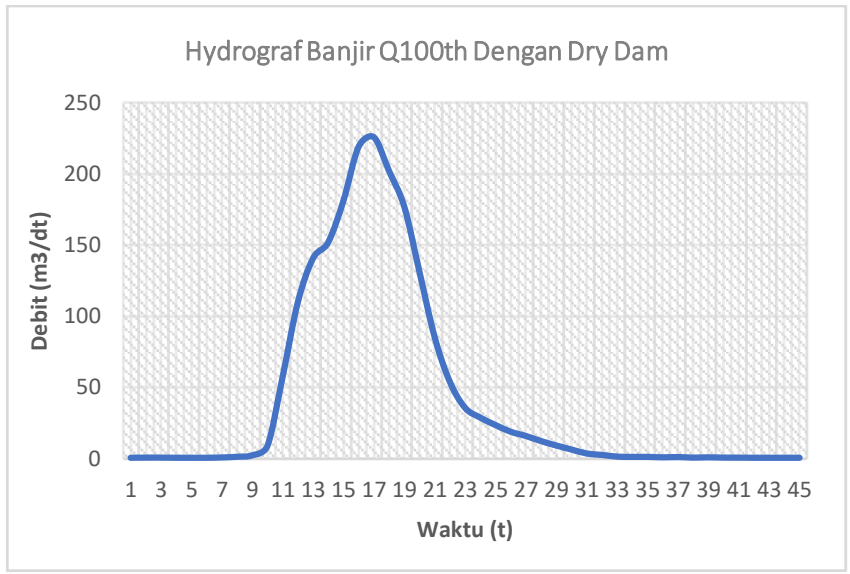

Gambar 6. Hydrograf Banjir dengan Rencana Dry Dam pada Sungai Bringin

Hasil simulasi debit banjir yang berada di DAS Bringin menggunakan metode SCS pada perangkat lunak HEC-HMS diketahui bahwa dengan adanya penambahan tampungan dapat mereduksi banjir pada Sungai Bringin. Rekapitulasi debit banjir sebelum dan sesudah ada tampungan dapat dilihat pada Tabel 3 dan Gambar 7.

Tabel 3. Rekapitulasi Debit Banjir

\begin{tabular}{|c|c|c|c|c|c|c|c|}
\hline \multirow{2}{*}{ Keterangan } & \multicolumn{3}{|c|}{ Debit $100^{\text {th }}\left(\mathrm{m}^{3} / \mathrm{dt}\right)$} & \multicolumn{2}{c|}{ Reduksi $\left(\mathrm{m}^{3} / \mathrm{dt}\right)$} & \multicolumn{2}{c|}{$\begin{array}{c}\text { Persentase (\%) } \\
\text { Reduksi Banjir }\end{array}$} \\
\cline { 2 - 8 } & Eksisting & $\begin{array}{c}\text { Small } \\
\text { Dam }\end{array}$ & $\begin{array}{c}\text { Dry } \\
\text { Dam }\end{array}$ & $\begin{array}{c}\text { Small } \\
\text { Dam }\end{array}$ & $\begin{array}{c}\text { Dry } \\
\text { Dam }\end{array}$ & $\begin{array}{c}\text { Small } \\
\text { Dam }\end{array}$ & $\begin{array}{c}\text { Dry } \\
\text { Dam }\end{array}$ \\
\hline $\begin{array}{c}\text { Hilir } \\
\text { Sungai } \\
\text { Bringin }\end{array}$ & 436,4 & 284,6 & 225,6 & 151,8 & 210,8 & 34,8 & 48,3 \\
\hline
\end{tabular}






Gambar 7. Rekapitulasi Hydrograf Banjir Sungai Bringin

\section{KESIMPULAN}

Pengendalian banjir Sungai Bringin dapat dilakukan dengan mereduksi debit pada tampungan di hulu DAS. Pemodelan tampungan dapat berupa embung atau dengan dry dam. Debit banjir Sungai Bringin yang diperoleh dengan menggunakan HEC-HMS pada kondisi eksisting adalah sebesar 436,4 m3/dt. Dengan adanya rencana Embung debit yang diperoleh adalah sebesar 284,6 m3/dt, maka besarnya banjir yang terreduksi dapat di perhitungkan sebesar 151,8 m3/dt atau 34,8 persen. Sedangkan dengan adanya Rencana Dry Dam Debit banjir diperoleh sebesar $225,6 \mathrm{~m} 3 / \mathrm{dt}$, maka besarnya banjir yang terreduksi dapat di perhitungkan sebesar $210,8 \mathrm{~m} 3 / \mathrm{dt}$ atau 48,3 persen.

\section{SARAN}

Berdasarkan hasil penelitian yang telah dilakukan perlu adanya perbaikanperbaikan yang harus dilakukan untuk perbaikan dan pemeliharaan bangunan pemecah gelombang maupun untuk penelitian selanjutnya yang sejenis, Adapun beberapa hal yang dapat dijadikan rekomendasi adalah sebagai berikut: 1) Perlu adanya studi morfologi Sungai Bringin yang dipengaruhi oleh adanya pembangunan Dry Dam. 2) Perlu adanya analisis Sedimentasi dan Erosi untuk menghitung besarnya Biaya Operasional dan Pemeliharaan Dry Dam.

\section{DAFTAR RUJUKAN}

Asdak, Chay. (1995). Hidrologi dan Pengelolaan DAS.Yogyakarta: University Press, Gajah Mada

Binilang, A., \& Sumarauw, J. S. F. (2018). Analisis Debit Banjir Dan Tinggi Muka Air Sungai Palaus, 6(4), 235-246.

Grigg, Neil. (1996). Water Resources Management: Principles, Regulations, and Cases. McGraw-Hill.

Handayani, D., \& Ningsih, U. (2017). Metode Thiessen Polygon untuk Ramalan Sebaran Curah Hujan Periode Tertentu pada Wilayah yang Tidak Memiliki Data Curah Hujan Metod. Jurnal Teknologi Informasi DINAMIK Volume, 17(2), 154-163.

Isma Fajar., \& Teddy W. Sudinda (2019) Analisis Bendungan Kering (Dry Dam) 
Ciawi Sebagai Upaya Pengendalian Banjir Dki Jakarta. Prosiding Seminar Intelektual Muda \#2, Peningkatan Kualitas Hidup dan Peradaban Dalam Konteks IPTEKSEN 5 (Sept),338-342.

Kodoatie, R.J. dan Sugiyanto, (2002). Banjir, Beberapa Penyebab dan Metode Pengendaliannya dalam Perspektif Lingkungan, Pustaka Pelajar, Yogyakarta.

Kejadian Banjir Sungai Bringin dan Sungai Plumbon https://bpusdatarubk.jatengprov.go.id/index.php/sejarah/86-berita/146-berita5

Lempérière F. (2006). The role of dams in the XXI century. Achieving a sustainable

development target, Hydropower and Dams, Issue Three, pp. 99-108.

Muhammad Ficky Meilaci Wibowo, Randy Arnatha, Suharyanto, Dwi Kurnian,(2014), Pemenuhan Kebutuhan Air Irigasi Melalui Pembangunan Long Storage

Oshikawa Hideo, Imamura Tomohiko, Komatsu Toshimitsu. (2012). Study on the flood control ability of a dry dam used as a flood retarding basin in a river. Journal of Japan Society of Civil Engineers. 67[4]: 667-672

Soedibyo. (1993). Teknik Bendungan. PT. Pradnya Paramita. Jakarta

Soemarto, C.D. (1986). Hidrologi Teknik. Surabaya: Penerbit Usaha Nasional

Soemarto. (1999). Hidrologi Teknik. Jakarta: Penerbit Erlangga

Sosrodarsono,S dan Takeda,K. (2003). Hidrologi Untuk Pengairan. Jakarta: Pradnya Paramita

Sosrodarsono, Suyono Dr.Ir. dan Tominaga, Masateru Dr., Editor, (1985). Perbaikan dan Pengaturan Sungai. Penerjemah Ir Yusuf Gayo dkk., Penerbit PT Pradnya Paramita Jakarta.

Sri Harto, BR. (2000). Hidrologi: Teori, Masalah, Penyelesaian. Yogyakarta: Nafiri Offset

Suripin. (2001). Pelestarian Sumber Daya Tanah dan Air. Penerbit Andi, Yogyakarta.

Suseno Darsono, Ratih Pujiastuti, Lilis Suryani, Susilowati.(2016). Penelitian Rekayasa Perlintasan Sungai Bringin dan Jalan Tol Semarang Barat

Reskiana, F. (2004). TEKNOLOGI DALAM PERLINDUNGAN SUNGAI (Vol. 1). Bogor.

Roslan Zainal Abidin, Mohd Sofiyan Sulaiman*, N. Y. (2017). Erosion risk assessment: A case study of the Langat River bank in Malaysia. International Soil and Water Conservation Research, 5(July), 26-35. https://doi.org/10.1016/j.iswcr.2017.01.002

Rosyidie, Arif. (2013). Banjir: Fakta dan Dampaknya, Serta Pengaruh dari Perubahan Guna Lahan. Jurnal Perencanaan Wilayah dan Kota, Volume 24 No.3. Bandung: Fakultas Sekolah Arsitektur, Perencanaan, dan Pengembangan Kebijakan, Institut Teknologi Bandung.

Twenty-Sixth International Congress on Large Dams / Vingt-Sixième Congrès International des Grands Barrages: 4th - 6th July (2018), Vienna, Austria

Undang-Undang Nomor 17 tahun (2019) tentang Sumber Daya Air, Kemenkumham

U.S. Army Corps of Engineers Institute for Water Resources. (2018). Hydrologic Modeling System Quick Start Guide. 